\title{
IKAN GABUS (Channa striata) MANFAAT PENGEMBANGAN DAN ALTERNATIF TEKNIK BUDIDAYANYA
}

\author{
Nurbakti Listyanto dan Septyan Andriyanto \\ Pusat Riset Perikanan Budidaya \\ Jl. Ragunan 20, Pasar Minggu, Jakarta Selatan 12540 \\ E-mail: lintang@ cria.indosat.net.id
}

\begin{abstract}
ABSTRAK
Ikan gabus (Channa striata) merupakan jenis ikan yang bernilai ekonomis. Di Indonesia penyebarannya antara lain di Sumatera, Jawa, Kalimantan, Sulawesi, dan Papua. Spesies ini memiliki rasa yang khas, tekstur daging tebal dan putih sehingga harganya pun cukup mahal baik dalam bentuk segar maupun kering (ikan asin). Selain itu, memiliki kandungan albumin yang diperlukan tubuh manusia dalam mengatasi berbagai penyakit terutama yang disebabkan berkurangnya jumlah protein darah. Ikan ini termasuk salah satu jenis ikan karnivora air tawar dikarenakan sifatnya yang gemar memangsa ikan-ikan kecil sebagai pakannya. Walaupun memiliki potensi strategis serta kegunaan yang luas dalam industri pangan maupun farmasi, namun di Indonesia masih belum banyak dibudidayakan karena belum dikuasai teknik budidayanya. Pemeliharaan bersama ikan mujair di kolam, penggunaan campuran pakan buatan kaya nutrisi, serta pemanfaatan tanaman air dalam proses pemijahan merupakan alternatif budidaya yang perlu dikembangkan.
\end{abstract}

KATAKUNCl: gabus, albumin, pakan buatan, budidaya

\section{PENDAHULUAN}

Ketersediaan lahan budi daya jenis ikan konsumsi air tawar di Indonesia memberikan peluang besar bagi masyarakat bahkan pengusaha untuk mengembangkan budi daya ikan gabus. Permintaan dan kebutuhan pasar lokal maupun luar negeri semakin meningkat seiring dengan meningkatnya nilai produksi budidaya Channa striata tiap tahunnya. Data statistik FAO (2000) menyebutkan jumlah produksi Channa striata dari hasil budidaya pada tahun 2003 sebanyak 5.448 ton dan meningkat pada tahun 2004 mencapai 11.498 ton, sedangkan dari hasil tangkapan pada tahun 2003 sebanyak 7.327 ton dan meningkat pada tahun 2004 sebesar 16.528 ton. Berdasarkan data di atas memperlihatkan bahwa peluang bisnis budidaya spesies ini menjadi semakin prospektif dan strategis. Jenis-jenis ikan air tawar ekonomis dan strategis di Indonesia yang sudah dikenal dan diperdagangkan secara luas adalah ikan mas, tawes, nilem, jelawat, kowan (grasscarp), patin, baung, lele (lokal dan dumbo), gurami, tambakan, betutu, nila, belut, sidat, dan gabus. Khusus ikan gabus (Channa striata) (Gambar 1) merupakan jenis ikan air tawar yang bersifat karnivora namun memiliki banyak manfaat baik dari segi nilai ekonomisnya maupun manfaat dalam bidang kesehatan.

Review ini ditulis untuk mediasi berbagai pelaku di bidang perikanan budidaya untuk memberdayakan dan mengembangkan ikan gabus yang selama ini dikenal sebagai hama dalam kolam budidaya, agar ke depan dapat diupayakan sebagai ikan peliharaan yang bermanfaat serta sebagai komoditas unggulan budidaya perikanan air tawar.

\section{DESKRIPSI IKAN GABUS}

Ikan gabus merupakan salah satu jenis ikan karnivora air tawar yang menghuni kawasan Asia Tenggara, namun belum banyak diketahui tentang sejarah dan sifat biologisnya. Ikan jenis ini dikenal sebagai ikan konsumsi dan banyak ditemui di pasaran. Dalam ukuran kecil (anakan) ikan gabus terlihat eksotis sehingga banyak dimanfaatkan sebagai ikan hias dalam akuarium (Gambar 2). Di Indonesia, ikan ini dikenal dengan banyak nama daerah yaitu aruan, haruan (Malaysia, Banjarmasin, Banjarnegara), kocolan (Betawi), bogo (Sidoarjo), bayong, licingan (Banyumas), kutuk (Jawa). Dalam bahasa Inggris antara

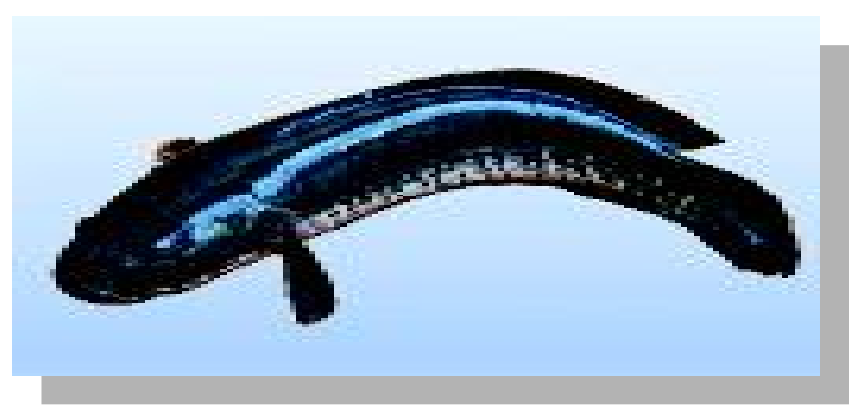

Gambar 1. Ikan gabus (Channa striata) 


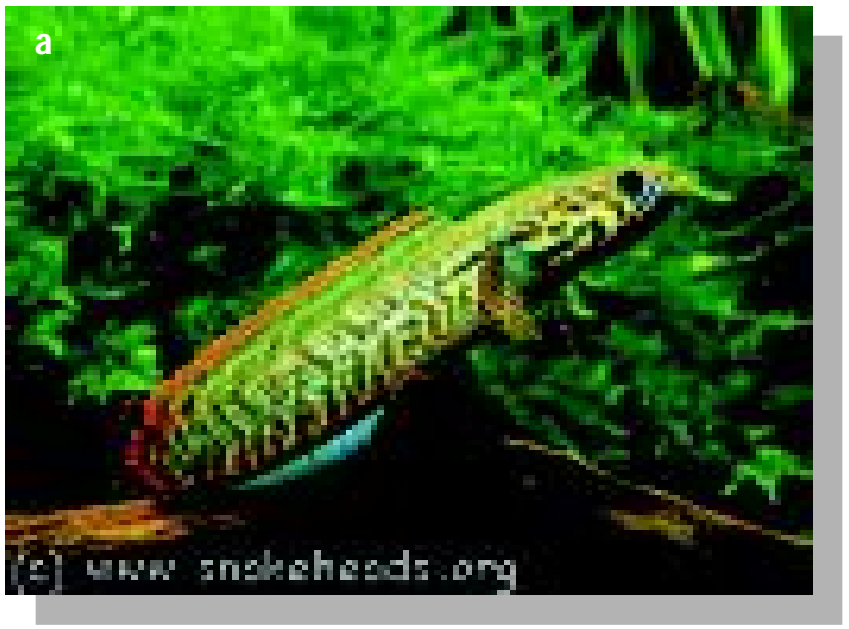

lain common snakehead, snakehead murrel, chevron snakehead, dan stripped snakehead. Weber \& Beaufort (1922) menyebutkan beberapa nama daerah Channa striata antara lain gabus (Malaysia, Jawa), rajong (Sunda), deluk, kuto (Jawa, Madura), bado (Gaju), bace (Aceh), sepunkat (Palembang), dan haruan (Banjarmasin).

\section{Klasifikasi}

Ikan gabus dalam taksonomi dapat diklasifikasikan sebagai berikut:

Kingdom : Animalia

Filum : Chordata

Kelas : Actinopterygii

Ordo : Perciformes

Familia : Channidae

Genus : Channa

Species : Channa striata

(Bloch, 1793 dalam Weber \& Beaufort, 1922).

Synonyms:

- Ophiocephalus wrahl (Lacepede, 1801: 552)

- Ophiocephalus wrahl (Hamilton, 1822:60, 367)

- Ophiocephalus chena (Hamilton, 1822: 62, 367)

- Ophiocephalus planiceps (Cuvier, 1831: 424)

- Ophiocephalus sowarah (Bleeker, 1845)

- Ophiocephalus vagus (Peters, 1868: 260)

- Ophiocephalus philippinus (Peters, 1868: 262)

\section{Morfologi}

Tubuh ikan gabus umumnya berwarna coklat sampai hitam pada bagian atas dan coklat muda sampai keputihputihan pada bagian perut. Kepala agak pipih dan

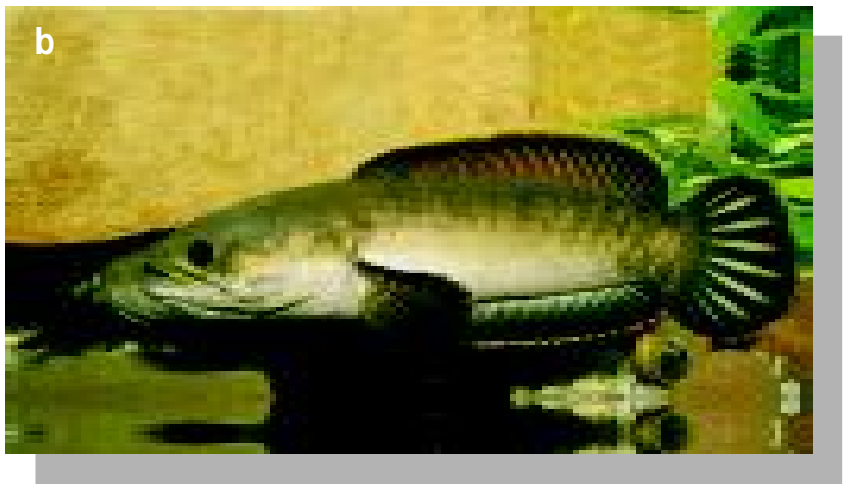

Gambar 2. (a) Channa bleheri (b) Channa gachua dimanfaatkan sebagai ikan hias dalam akuarium air tawar (www. snakeheads.org)

bentuknya seperti ular dengan sisik-sisik besar di atas kepala, oleh sebab itu, dijuluki sebagai "snake head" (Gambar 3). Sisi atas tubuh ikan gabus dari kepala hingga ke ekor berwarna gelap, hitam kecoklatan atau kehijauan. Sisi bawah tubuh berwarna putih mulai dagu ke belakang. Sisi samping bercoret tebal (striata, bercoret-coret) dan agak kabur, warna tersebut seringkali menyerupai lingkungan sekitarnya. Mulut ikan gabus besar, dengan gigi-gigi yang tajam. Sirip punggung (Gambar 4) memanjang dengan sirip ekor membulat di bagian ujungnya.

\section{Penyebaran}

Channa merupakan jenis ikan air tawar dengan 30 spesies yang tersebar dari Afrika hingga Asia (Lim \& Ng, 1990). Di Asia spesies ini tersebar dari Afghanistan, Pakistan bagian barat, Nepal bagian selatan, India,

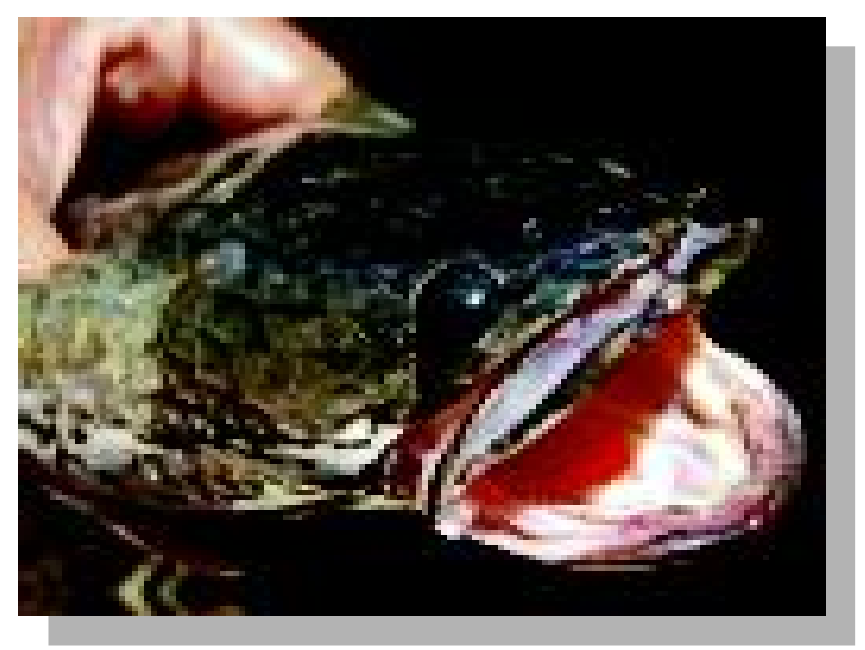

Gambar 3. Bentuk kepala ikan gabus yang menyerupai ular (snake head) (www.practicalfishkeeping. co.uk) 


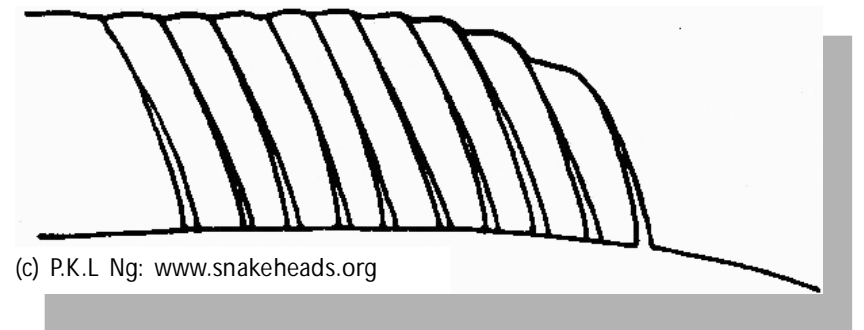

Gambar 4. Bentuk sirip punggung C. striata : susunan sirip pertama lebih pendek dibanding yang kedua dan susunan sirip berikutnya sama panjang/sejajar (Lim \& Ng, 1990)

Bangladesh, Srilangka, Myanmar, Indo-China, Cina, Jepang, Taiwan, Philipina, Malaysia, Singapura, dan Indonesia bagian barat. Asia Tenggara menjadi pusat penyebaran ikan gabus dengan 10 spesies didalamnya, menurut Lim $\& N g$ (1990) sebanyak lima spesies tersebar di negara Singapura, Malaysia, dan Indonesia antara lain Channa micropeltes, Channa striata, Channa lucius, Channa melasoma, dan Channa gachua. Beberapa spesies Channa yang tersebar di Malaysia, Singapura, Sumatera, Kalimantan (Borneo) antara lain Channa sp. (Scopoli, 1777), Channa bankanensis (Bleeker, 1852), Channa gachua (Hamilton-Buchanan, 1822), Channa lucius (Cuvier \& Valenciennes, 1831), Channa marulioides (Bleeker, 1851), Channa melanoptera (Bleeker, 1855), Channa melasoma (Bleeker, 1851), Channa micropeltes Cuvier \& Valenciennes, 1831), Channa pleurophthalma (Bleeker, 1851), dan Channa striata (Bloch, 1793).

\section{Habitat}

Ikan gabus umumnya didapati pada perairan dangkal seperti sungai dan rawa dengan kedalaman $40 \mathrm{~cm}$ dan cenderung memilih tempat yang gelap, berlumpur, berarus tenang, ataupun wilayah bebatuan untuk bersembunyi. Selain itu, spesies ini juga ditemui di danau serta saluransaluran air hingga ke sawah-sawah. Day (1967) dalam Tjahjo \& Purnomo (1998) menyatakan bahwa ikan gabus termasuk salah satu jenis ikan air tawar yang mempunyai penyebaran yang luas, dan secara alami dapat hidup di danau, sungai, rawa air tawar, dan sawah. Sedangkan menurut Muflikhah (2007) benih ikan gabus banyak ditemukan di daerah perairan yang banyak rerumputan atau tanaman air dan belukar yang terendam air.

\section{Kebiasaan Hidup}

Secara umum ikan gabus (Channa striata) memiliki pola pertumbuhan allometrik atau pertambahan bobot lebih cepat daripada pertambahan panjang badan, hal ini berkaitan dengan sifat agresifnya dalam mencari makan.
Ikan ini memangsa berbagai ikan kecil, serangga, dan berbagai hewan air lain termasuk berudu dan kodok. Seperti dinyatakan Uchida \& Fujimoto (1933) bahwa makanan alami ikan gabus berupa hewan-hewan akuatik seperti ikan-ikan kecil, kodok serta insekta air.

Ikan gabus memiliki kemampuan bernapas langsung dari udara, dengan menggunakan semacam organ labirin bernama divertikula yang terletak di bagian atas insang sehingga mampu menghirup udara dari atmosfir (Lagler et al., 1993 dalam Muflikhah, 2007). Sebagaimana ikanikan yang mempunyai labirin, ikan gabus mampu bertahan dalam kondisi perairan rawa dengan kandungan oksigen terlarut rendah dan $\mathrm{pH}$ berkisar 4,5--6.

Dalam proses pemijahan spesies ini memiliki kebiasaan membangun sarang berbusa di antara vegetasi di lingkungan hidupnya. Djajadireja et al., (1977) dalam Muflikhah (2007) menyatakan bahwa ikan gabus membuat sarang yang berbentuk busa di sekitar tanaman air di rawa dan perairan dangkal dengan arus lemah. Busa tersebut berbentuk semacam lingkaran yang berfungsi selain sebagai area pemijahan juga sebagai pelindung telur yang telah dibuahi.

\section{NILAI EKONOMIS}

Ikan gabus merupakan jenis ikan karnivora yang memiliki nilai ekonomis. Lim \& Ng (1990) menyebutkan bahwa di Singapura Channa micropeltes, C. Striata, dan C. lucius merupakan jenis ikan konsumsi dengan harga jual dalam keadaan segar berkisar antara S\$10--S\$20 per kilogram atau sekitar Rp 65.000,---sampai Rp 130.000,. Di Thailand ikan ini telah menjadi makanan favorit dan telah di ekspor ke Arab Saudi, sedangkan di Indonesia harga pasar domestik untuk produk olahan mencapai $\mathrm{Rp}$ 20.000,- hingga Rp 30.000,- per kg.

Ikan gabus asin merupakan salah satu produk yang harganya cukup mahal. Di Sumatera dan Kalimantan umumnya ikan ini diasinkan terlebih dahulu sebelum diperdagangkan antar pulau. Dalam penyediaan produk ikan asin (Gambar 5) setiap harinya dibutuhkan rata-rata $150 \mathrm{~kg}$ bahan baku dari jenis ikan gabus. Produk ikan asin dijual dengan harga bervariasi yaitu antara Rp 22.000,hingga $\mathrm{Rp} 55.000$,- per kg.

Ikan ini memiliki kemampuan bernapas langsung dari udara dan memiliki tingkat mortalitas yang rendah, sehingga hal ini merupakan keuntungan komersial dalam proses transportasi ikan gabus dalam keadaan hidup.

Ikan gabus digemari masyarakat karena mempunyai tekstur daging yang putih dan tebal dengan cita rasa yang khas, serta tidak mempunyai duri selip (Makmur, 2004), 


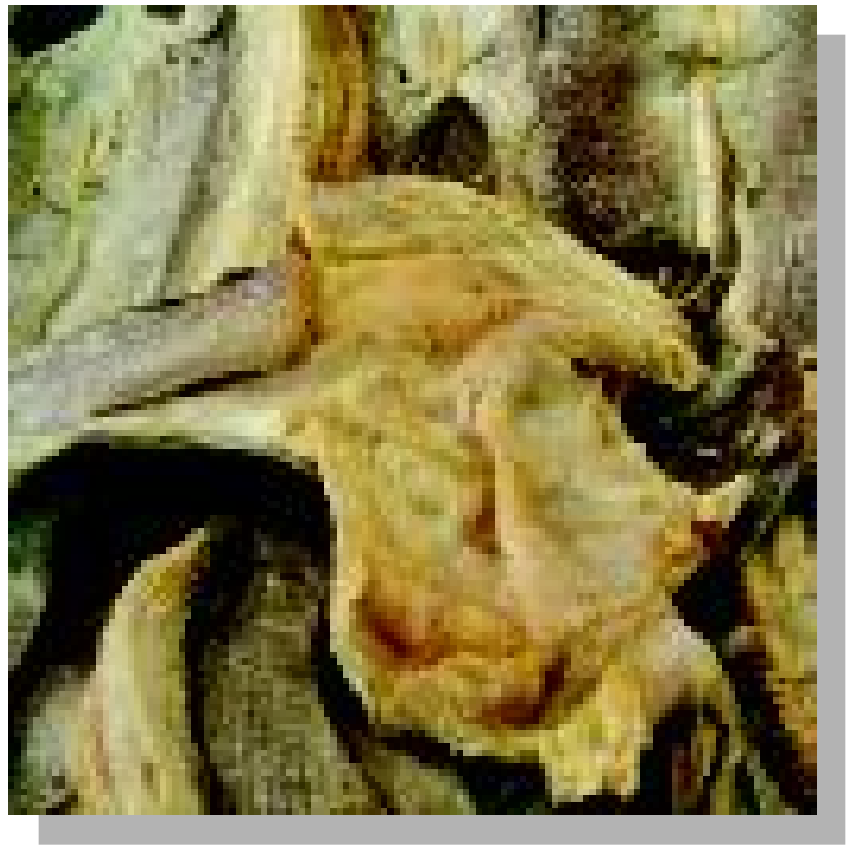

Gambar 5. Produk asin ikan gabus

yang menyebabkan ikan gabus merupakan jenis yang paling banyak digunakan untuk produk olahannya seperti pempek, kerupuk maupun olahan lainnya (Muflikhah, 2007). Dengan melihat kenyataan ini, bisnis ikan asin ini dipastikan menjadi bisnis yang prospektif. Selain pangsa pasarnya yang masih luas, sumber bahan bakunya juga sangat melimpah apabila dimanfaatkan secara optimal.

\section{TANTANGAN BUDIDAYA DAN INOVASI SEDERHANA}

Ikan gabus merupakan ikan asli perairan tawar di daerah tropis seperti Asia dan Afrika. Ikan ini telah banyak dipelihara secara komersil di negara-negara seperti Thailand, Philipina, Vietnam, dan M yanmar. Di Indonesia ikan gabus belum banyak dibudidayakan karena belum dikuasainya sepenuhnya dalam hal teknik pembenihan dan teknik pembesarannya. Muflikhah (2007) menyebutkan beberapa kendala dalam pengembangan ikan gabus antara lain: 1) Terbatasnya pengetahuan mengenai teknik budidaya; 2) Terbatasnya pakan yang sesuai, mudah dan murah untuk mendukung pertumbuhan ikan gabus yang optimal; dan 3) Terbatasnya sumberdaya manusia terdidik yang mencukupi untuk memberikan penyuluhan kepada nelayan dan pembudidaya. Keberhasilan negara-negara tetangga tersebut merupakan tantangan tersendiri bagi para pembudidaya di Indonesia untuk mampu mengembangkan serta menjadikan ikan gabus sebagai komoditas unggulan. Selain itu, peningkatan kualitas sumberdaya manusia pendukung perlu segera diwujudkan sehingga berbagai kendala dalam pengembangannya dapat diminimalisasi.
Hasil tangkapan Channa striata cenderung semakin meningkat setiap tahunnya. Kondisi tersebut cukup mengkhawatirkan karena dapat mengancam keberadaan plasma nutfah serta keragaman populasinya di alam, sehingga peningkatan produksi melalui kegiatan budidaya perlu dipacu perkembangannya untuk memenuhi kebutuhan pasar sekaligus mengurangi kegiatan penangkapan di alam. Data statistik FAO (2000) memperlihatkan bahwa hasil tangkapan Channa striata secara global jumlahnya masih melebihi hasil produksi budidayanya. Keragaan hasil tangkapan dan produksi hasil budidaya secara global menurut sumber FAO (2000) dapat dilihat pada grafik (Gambar 6).

Spesies ini dalam kegiatan budidaya perikanan dapat sangat merugikan apabila dipelihara bersamaan dengan ikan peliharaan lain dalam satu kolam, terutama apabila ikan peliharaan masih berukuran kecil. Apalagi, apabila ikan gabus yang berukuran besar dapat mencapai panjang sekitar 1 meter tentunya berbahaya bagi manusia. Di Amerika Utara, ikan gabus dan beberapa kerabat dekatnya yang termasuk snakehead fishes diwaspadai sebagai ikan berbahaya, yang dapat mengancam kelestarian biota perairan. Oleh karena sifatnya yang buas dan invasif serta dapat meloncat ke kolam-kolam pemeliharaan untuk memakan bibit ikan budidaya, maka dikhawatirkan ikan gabus akan cepat meluas dan merusak keseimbangan alam perairan. Namun dengan melihat kerugian yang diakibatkan ikan ini, hendaknya justru dapat memacu seluruh pelaku kegiatan budidaya di Indonesia untuk menciptakan suatu paket teknologi ataupun teknik maupun inovasi manipulatif yang mampu memanfaatkan sifat-sifat merugikan yang dimiliki spesies ini menjadi sesuatu yang menguntungkan. Seperti dinyatakan Tjahjo \& Purnomo (1998) dalam tingkat trofik pada perairan (rawa), ikan gabus termasuk (top carnivore) yang berperan penting dalam mengatur keseimbangan antar populasi ikan herbivora maupun avertebrata.

\section{PELUANG BUDIDAYA}

Ikan gabus mempunyai kecenderungan sebagai pemangsa, sehingga dalam usaha budidaya hal tersebut dapat menjadi kendala utama. Namun saat ini melalui serangkaian penelitian tentang pakan menunjukkan bahwa ikan gabus dapat dibudidayakan dan dapat tumbuh baik dengan pemberian pakan buatan. Hasil penelitian Muflikhah (2007) menyebutkan pakan yang digunakan berupa campuran dedak dan ikan rucah baik dari ikan air tawar maupun ikan laut, juga sumber pakan hewani lain seperti keong mas. Pemberian campuran pakan hewani dimaksudkan untuk memenuhi kebutuhan nutrisi benih ikan gabus sampai ukuran konsumsi. 

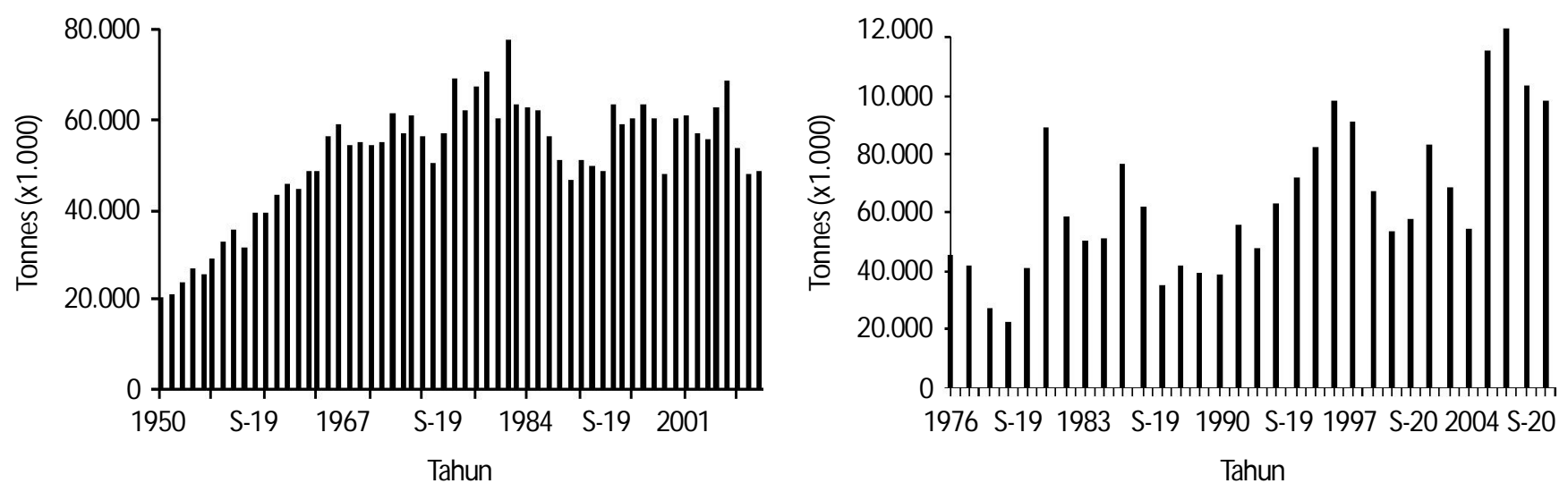

Gambar 6. (a) Jumlah produksi global Channa striata dari hasil tangkapan, (b) Jumlah produksi global Channa striata hasil budidaya

Salah satu konsep manipulasi kultur dapat digunakan sebagai teknik budidaya ikan gabus yang perlu dikembangkan. Ikan ini dapat dipelihara "bersamaan" dengan ikan mujair (induk). Dengan sifat karnivornya ikan gabus akan memangsa anak ikan mujair sehingga suplai makanan secara alami langsung didapatkan dari hasil kegiatan pemeliharaan bersama di kolam. Seperti dinyatakan Tjahjo \& Purnomo (1998) bahwa di perairan (rawa) lebih dari 90\%makanan ikan gabus adalah anak ikan mujair ukuran 3--5 cm. Pemilihan ikan mujair dikarenakan ikan ini relatif cepat memijah, tidak memerlukan perawatan khusus dalam pemeliharaannya serta mampu menghasilkan banyak anakan yang dapat dimanfaatkan sebagai umpan/mangsa hidup.

Wijeyaratne (1992) dalam Cholik et al. (2005) mengatakan bahwa untuk budidaya ikan gabus digunakan kolam yang luasnya $172 \mathrm{~m}^{2}$ dan $160 \mathrm{~m}^{2}$ dengan kedalaman $100 \mathrm{~cm}$. Kedua kolam itu dipupuk dan ditebari ikan wader (Puntius punctatus) dengan kepadatan $20 \mathrm{ekor} / \mathrm{m}^{2}$ luas lahan sebagai ikan mangsa. Menurut Suryanti et al. (1997) untuk budidaya di keramba digunakan ikan-ikan kecil sebagai pakan dan terdapat enam jenis di antaranya yaitu benih jelawat (Leptobarbus hoeveni), kendia (Thynichthys voilanti), repang (Puntius nini), puyau (Osteochilus hasselti), sepat (Trichogaster spp.), dan biawan (Helostoma temmincki).

Padat penebaran ikan gabus selama pembesaran dengan bobot awal $100 \mathrm{~g} /$ ekor adalah 50--60 ekor $/ \mathrm{m}^{2}$. Setelah masa pemeliharaan selama 3--5 bulan bobot tubuh mencapai 500 g/ekor. Dalam penelitiannya Suryanti et al. (1997) menyatakan bahwa setelah benih mencapai bobot $10 \mathrm{~g} /$ ekor ditebar dalam hapa (keramba) hingga mencapai ukuran 700--1.000 g/ekor dengan masa pemeliharaan berkisar antara 10 sampai 12 bulan. Penggunaan keramba dalam pemeliharaan dapat dilakukan di sungai, danau atau rawa.
Berdasarkan hasil pengamatan diketahui bahwa benih ikan gabus banyak ditemukan di perairan yang banyak ditumbuhi tanaman air atau rerumputan yang terendam air. Dalam teknik pembenihan, tanaman air mampu merangsang pemijahan ikan gabus. Hal ini dikarenakan pada tanaman air banyak terdapat pakan alami berupa jasad renik terutama dari kelompok protozoa dan rotifera sebagai penyedia pakan alami bagi larva yang dihasilkan. Hal ini berhubungan dengan perilaku induk yang menunjukkan bahwa induk tidak akan memijah apabila tidak ada kepastian tersedianya makanan yang sesuai dan cukup untuk anak-anaknya (Gambar 7). Hal tersebut seperti hasil penelitian yang dilakukan M uflikhah (2007) bahwa adanya tanaman air berupa tanaman padi yang tumbuh di sela-sela keramba menjadi rangsangan pemijahan bagi ikan. Sebaliknya ikan gabus yang dipelihara dalam keramba namun tidak ada tanaman airnya ternyata tidak ditemukan atau didapatkan benih, sementara induk yang dipelihara umumnya matang gonad.

Spesies ini kebanyakan membangun sarang berbusa di antara vegetasi di rawa-rawa dan sungai berarus lambat. Telur-telurnya yang dibuahi diletakkan di bawah sarang dan kemudian mengambang di atas sarangnya dan dijaga oleh induknya sampai kira-kira panjangnya mencapai 50 $\mathrm{mm}$. Ikan-ikan muda seringkali berenang bersama dan membentuk kelompok yang padat (Dinas Kelautan dan Perikanan Provinsi Jambi, 2006).

Chai (1990) menyebutkan bahwa kolam yang digunakan untuk pemijahan ikan gabus (Channa maculata) berupa kolam tanah yang kaya dengan vegetasi (tanaman) air namun rendah tingkat pertumbuhan planktonnya. Perbandingan jantan betina yaitu 1:2 atau 1:3. Selama pemeliharaan induk diberi pakan ikan nila hidup sebanyak 30--40 g/induk. Induk jantan menyiapkan sarang dengan membersihkan vegetasi di sekitar sarangnya. Betina 


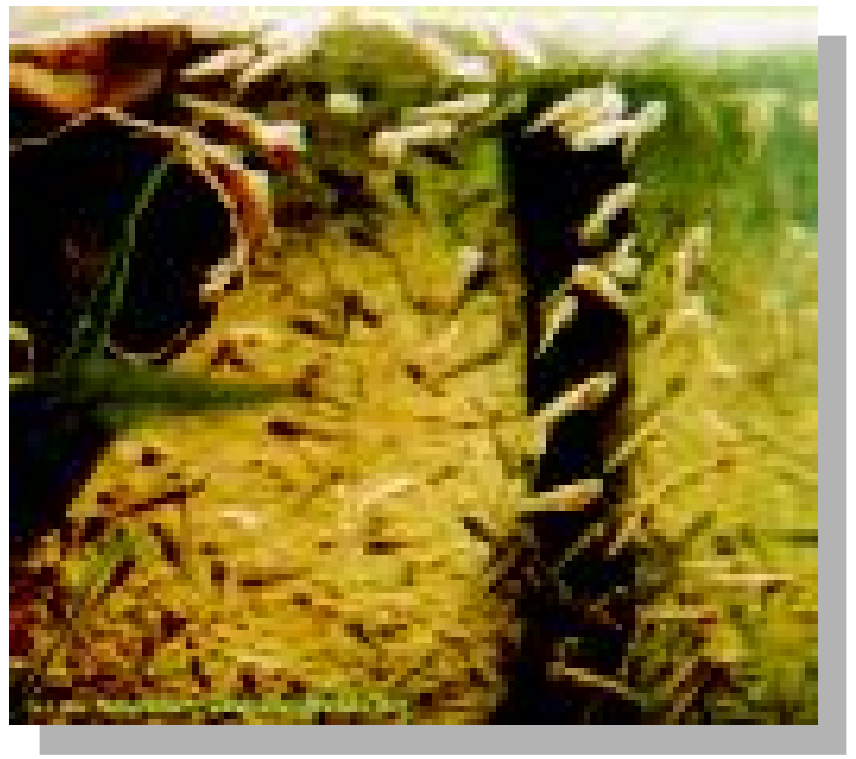

Gambar 7. Benih Channa sp. Himalaya berkumpul di bawah gelembung udara (Schnieder, 2003)

berukuran $35 \mathrm{~cm}$ dapat menghasilkan 10.000 butir telur dan setelah proses pemijahan kedua induk tinggal di sekitar sarang untuk menjaga telur dan larvanya.

\section{DUKUNGAN RISET UNTUK PAKAN IKAN GABUS}

Penelitian mengenai pakan larva telah dilakukan di dalam akuarium maupun di kolam dengan menggunakan hapa. Penelitian menggunakan akuarium yang berukuran $30 \mathrm{~cm} \times 30 \mathrm{~cm} \times 30 \mathrm{~cm}$ dan disi air sebanyak 12,5 L. Larva ikan gabus yang digunakan berukuran 2,0--2,5 cm dengan bobot rata-rata 0,3 g/ekor, padat tebar sebanyak 25 ekor/ akuarium dan pakan yang diberikan berupa tubifex. Setelah 10 minggu pemeliharaan memberikan pertumbuhan sebesar 0,39 g (Seftriany, 2004 dalam Muflikhah, 2007). Untuk pemeliharaan benih di dalam hapa digunakan kolam tanah berukuran $3 \mathrm{~m} \times 5 \mathrm{~m} \times 1,5 \mathrm{~m}$ dengan keting gian air $0,75 \mathrm{~m}$. larva yang ditebar sebanyak 25 ekor/hapa dengan ukuran 1,4 cm dan bobot 0,08 $\mathrm{g}$, setelah 6 ming gu pemeliharaan hasil yang diperoleh menunjukkan bahwa pakan yang sesuai adalah pakan berupa cacing rambut (tubifek), dengan pertumbuhan senilai 2,7 g (M uflikhah $\&$ Nurdawati, 2003 dalam M uflikhah, 2007).

Penggunaan pakan buatan dalam budidaya ikan gabus telah diujicobakan. Pakan yang digunakan sebagai perlakuan adalah pelet dengan kadar protein (30\% 35\% dan $40 \%$ dan ransum harian (3\% dan $5 \%$ ). Sebagai pembanding adalah ikan gabus yang diberi ikan rucah (ikan putihan) sebanyak $9 \%$ bobot biomassa per hari. Tingkat sintasan yang dihasilkan antara jumlah ransum harian 3\% dan 5\%tidak berbeda, baik pada kadar protein 35\%maupun
$40 \%$ Ikan gabus yang diberi pelet mempunyai tingkat sintasan di atas $50 \%$ lebih besar dari ikan gabus yang diberi ikan rucah $(47,34 \%$. Pertumbuhan terbaik pada pemeliharaan ikan dalam keramba, yaitu dengan pemberian pelet berkadar protein $35 \%$ pada tingkat pemberian pakan 5\%bobot biomassa per hari (Suryanti et al., 1997).

Percobaan penambahan vitamin dalam pakan dilakukan pada benih ikan gabus dengan ukuran awal 70--73 g dan lama pemeliharaan enam minggu. Hasil penelitian menunjukkan bahwa penambahan $10 \mathrm{mg}$ vitamin $\mathrm{B} 5$ dan $30 \mathrm{mg}$ vitamin C dalam $1 \mathrm{~kg}$ pakan memberikan pertambahan bobot yang lebih tinggi dibandingkan hanya dengan penambahan vitamin B5 atau vitamin $C$ saja. Pertambahan bobot ikan dengan penambahan vitamin B5 dan vitamin $C$ dalam pakan adalah $47,81 \mathrm{~g}$ dan sintasan sebesar 98,81\% Penambahan vitamin B5 saja memberikan pertambahan bobot sebesar 42,943 g dan sintasan $97,02 \%$ sedangkan penambahan vitamin $\mathrm{C}$ saja dalam pakan memberikan pertambahan bobot sebesar $28,136 \mathrm{~g}$ dan sintasan 92,25\%(M uflikhah, 2007).

\section{MANFAAT PRODUK OLAHAN IKAN GABUS}

\section{Tepung Tulang Ikan}

Selama ini tulang ikan masih menjadi limbah dari sebagian besar industri perikanan. Seperti halnya di Palembang, ikan sebagai bahan baku pembuatan pempek, kerupuk dan makanan sejenis lainnya hanya memanfaatkan dagingnya saja. Sehingga dapat dipastikan bahwa tulang ikan gabus yang belum dimanfaatkan dan hanya akan menjadi limbah oleh setiap industri perikanan di Palembang. Salah satu upaya untuk memanfaatkan limbah tersebut adalah dengan mengolah limbah tulang ikan gabus menjadi tepung tulang kaya kalsium. Diharapkan dengan adanya upaya untuk memanfaatkan tulang ikan gabus sebagai bahan baku tepung tulang, dapat menjadi bahan tambahan makanan kaya kalsium yang siap disubstitusikan ke pangan lain. Hal tersebut sekaligus mampu mengoptimalkan usaha pengolahan hasil perikanan. Selain jumlah kalsium yang cukup dalam makanan yang dikonsumsi, penyerapan kalsium dari makanan juga merupakan faktor penting dalam pemeliharaan dan membangun tulang. Dengan demikian, diperlukan analisis fisiko-kimia dan sensoris pada tepung tulang. Dengan demikian interaksi komposisi zat gizi yang secara sinergis dapat mempengaruhi penyerapan kalsium dan menjamin bahwa bioavailibilitas kalsium dari bahan pangan dapat diharapkan dengan baik (Cashman, 2000 dalam Rafiswere, 2008). 
Pembuatan tepung ikan gabus selain bertujuan sebagai substitusi tambahan dalam penyediaan sumber protein (albumin), juga penyedia kalsium sebagai komponen utama pembuatan "food suplemen" dalam menghasilkan pakan yang berkualitas. Prospek bisnis tentunya terletak pada bagaimana memenuhi industri tepung ikan ataupun pakan ikan dalam diversifikasi produk olahan ikan di masa mendatang. Selain itu, kepala dan tulang ikan gabus hasil proses ekstraksi ataupun pengukusan dapat dimanfaatkan sebagai pakan ikan lele ataupun patin.

\section{Albumin untuk Kesehatan}

Berdasarkan penelitian yang telah dilakukan terungkap bahwa ikan gabus memiliki kandungan albumin tertinggi dibandingkan ikan laut dan ikan air tawar lainnya seperti ikan patin dan ikan gurami. Albumin merupakan salah satu jenis protein penting yang diperlukan tubuh manusia setiap hari bahkan dalam proses penyembuhan luka. Ikan gabus memiliki potensi strategis serta kegunaan yang luas dalam industri pangan maupun farmasi.

Albumin merupakan salah satu protein plasma darah yang disintesa di hati dan berperan penting menjaga tekanan osmotik plasma, mengangkut molekul-molekul kecil melewati plasma maupun cairan ekstra sel serta mengikat obat-obatan. Selain itu, al bumin dapat digunakan untuk mengatasi berbagai penyakit terutama yang disebabkan berkurangnya jumlah protein darah, seperti luka bakar, patah tulang, pasca operasi, dan infeksi paruparu.

Suprayitno (2008a) menyatakan albumin ikan gabus memiliki kualitas jauh lebih baik dari albumin telur yang biasa digunakan dalam penyembuhan pasien pasca bedah. Ikan gabus sendiri, mengandung 6,2\% albumin dan $0,001741 \% Z n$ dengan asam amino esensial yaitu treonin, valin, metionin, isoleusin, leusin, fenilalanin, lisin, histidin, dan arginin. Serta asam amino non-esensial meliputi asam aspartat, serin, asam glutamat, glisin, alanin, sistein, tiroksin, hidroksilisin, amonia, hidroksiprolin, dan prolin. Terkait kandungan albumin yang terdapat ada ikan gabus, diperoleh data bahwa kandungan albumin ikan gabus jantan sebesar 6,7\%lebih rendah dibanding ikan gabus betina yang memiliki kadar albumin $8,2 \%$

Albumin yang memiliki peran sedemikian besar, sampai saat ini masih impor dalam bentuk Human Serum Albumin (HSA) yang harganya sangat mahal. Untuk memperoleh crude albumin, dapat dilakukan dengan pengukusan ataupun ekstraktor vakum untuk memperoleh rendemen dan kualitas yang lebih baik. Ikan gabus melalui albuminnya sebagai penyusun HSA bisa dijadikan alternatif ketersediaan nutrisi dalam rangka memperbaiki gizi masyarakat Indonesia tanpa menggunakan biaya besar (Moedjiharto, 2008).

Penelitian dilakukan dalam pengobatan pasien menggunakan ikan gabus yang dikukus selama 60 menit dan disaring airnya, kemudian diminumkan pada pasien pasca operasi selama 8 hari. Hasilnya luka pasien akan lebih cepat sembuh dan tanpa efek samping. Hal ini dikarenakan kandungan protein yang tinggi dalam ikan gabus yang berfungsi dalam pembentukan sel-sel baru dalam tubuh pasien pasca operasi. Tingginya kandungan protein dari ikan gabus dapat dimanfaatkan untuk mengatasi gizi buruk. Gizi buruk ditandai dengan rendahnya kadar albumin, berada di bawah kadar normal 3,5--5,5 g/dl (Suprayitno, 2008b).

\section{ALTERNATIF BUDIDAYA UNTUK PENGEMBANGAN IKAN GABUS}

Teknik budidaya yang dapat dirujuk dalam rangka upaya pengembangan ikan gabus ke dalam komoditas perikanan budidaya terkait dengan pembenihan dan pembesarannya antara lain adalah:

- Pemanfaatan tanaman air dalam kolam pemijahan ikan gabus dapat diupayakan untuk merangsang induk ikan gabus sekaligus mempercepat proses pemijahan secara alamiah baik di kolam ataupun di keramba.

- Dalam pemeliharaan ikan gabus, sebagai pengganti pakan ikan rucah yang saat ini semakin sedikit, sulit didapatkan dan harganya relatif mahal, maka dapat diupayakan dengan pemberian pakan buatan berupa campuran pelet dan keong mas.

- Usaha pembesaran dapat dilakukan secara bersamaan dalam satu kolam dengan ikan pemakan plankton seperti tembakang (Helostoma teminckii), sepat (Tricogaster pectoralis), betok (Anabas testudineus), nila (Oreochromis niloticus). Namun, pemeliharaan bersama dengan ikan mujair akan lebih efisien dan efektif dikarenakan jenis ini lebih cepat memijah, sehingga anakan mujair dapat dimanfaatkan sebagai umpan hidup bagi ikan gabus peliharaan.

- Untuk membudidayakan ikan gabus sekaligus menjaga kelestariannya dapat dilakukan dengan sistem minapadi. Ikan gabus yang dikenal sebagai hama ikan budidaya, pada akhirnya akan menjadi komoditas peliharaan yang secara alami akan memijah (agar lestari) dan membesar (untuk panen) di ekosistem sawah. Dengan demikian, ikan gabus memiliki nilai tambah dalam kegiatan budidaya dengan sistem minapadi. 


\section{KESIMPULAN}

Ikan gabus yang selama ini dianggap sebagai hama dan selalu merugikan ternyata memiliki nilai ekonomis dengan harga jual yang tinggi baik dalam keadaan segar maupun olahan. Pangsa pasar yang luas serta melimpahnya sumber bahan baku menjadikan spesies ini sangat prospektif untuk dikembangkan di Indonesia.

Pengembangan beberapa alternatif dalam budidaya perlu dilakukan guna mengatasi terbatasnya penguasaan dalam teknik budidayanya. Alternatif yang diperlukan meliputi pemanfaatan tanaman air dalam kolam pemijahan untuk merangsang pematangan gonad induk, penggunaan pakan buatan kaya nutrisi berupa campuran pelet dan keong mas, pemeliharaan ikan gabus bersama dengan induk ikan mujair di mana anakan mujair dapat dimanfaatkan sebagai pakan hidup, serta penggunaan sistem minapadi dalam budidayanya.

\section{DAFTAR ACUAN}

Chai, L.C. 1990. Snakehead Culture. Aquaculture in Taiwan. Blackwell Scientific Publication. p. 39-42.

Cholik, F., Jagatraya, A.G., R.P. Poernomo, R.P., \& Jauzi, A. 2005. Ikan Gabus (Channa striata). Akuakultur Tumpuan Harapan Masa Depan Bangsa. Kerja sama Masyarakat Perikanan Nusantara dengan Taman Akuarium Air Tawar, TM II. 415 hlm.

Dinas Kelautan dan Perikanan Provinsi Jambi. 2006. Famili Channidae. Inventarisasi Keragaman Ikan Lokal Air Tawar Provinsi Jambi. $98 \mathrm{hlm}$.

FAO. 2000. Species Fact Sheet: Channa striata (Bloch, 1793). FAO Fisheries \& Aquaculture. http://www.fao.org/fishery/ species. Serial online 2000-2008. 2 pp.

Makmur, S. 2004. Pertumbuhan Ikan Gabus (Channa striata Bloch) Di Daerah Banjiran Talang Fatima DAS Sumatera Selatan. Jurnal Penelitian Perikanan Indonesia. Pusat Riset Perikanan Budidaya. 10(6): 1-6.

Moedjiharto, T.J. 2008. Kualitas Albumin Ikan Gabus Lebih Baik Dari Telur. ANTARA. http://www. antarajatim.com. Serial online $27 \mathrm{M}$ ei 2008. $2 \mathrm{hlm}$.

Muflikhah, N. 2007. Domestikasi Ikan Gabus (Channa striata). Prosiding Seminar Nasional Tahunan IV Hasil
Penelitian Perikanan dan Kelautan. Jurusan Perikanan dan Kelautan Universitas Gadjah Mada. hlm. 1- 10.

Lim, K.K.P. \& Ng, P.K.L. 1990. Snakeheads (Pisces: Channidae): Natural History, Biology and economic Importance. Department of Zoology, National University of Singapore. http://www.snakeheads.org. Serial online 2001-2006. 22 pp.

Rafiswere. 2008. Pembuatan Tepung Tulang Ikan Gabus Tinggi Kalsium Dengan Ekstraksi Basa. http:// one.indoskripsi.com. Serial online 19 Maret 2008. 1 hlm.

Schnieder, M. 2003. New Channa Experiences. Aquaristik Fachmagazin Nr. 171, p. 38-42. http:// www. snakeheads.org. Serial online 2001-2006.

Suprayitno, E. 2008a. Kualitas Albumin Ikan Gabus Lebih Baik Dari Telur. ANTARA. http://www. antarajatim.com. Serial online 27 M ei 2008. $2 \mathrm{hlm}$. 2008b. Ikan Gabus Sumber Protein Tinggi. http://suara-muhammadiyah. com. Serial online 1 Agustus 2008. $2 \mathrm{hlm}$.

Suryanti, Y., Priyadi, A., \& Suhenda, N. 1997. Pemberian Pakan Buatan Untuk Ikan Gabus (Chana striatus) dalam Keramba di Kalimantan Timur. Jurnal Penelitian Perikanan Indonesia. Pusat Riset Perikanan Budidaya. III(3): 35- 40.

Tjahjo, D.W.H. \& Purnomo, K. 1998. Studi Interaksi Pemanfaatan Pakan Alami Antar Ikan Sepat (Trichogaster pectoralis), Betok (Anabas testudineus), Mujair (Oreochromis mossambicus), Nila (0. niloticus) dan Gabus (Channa striata) di Rawa Taliwang. Jurnal Penelitian Perikanan Indonesia. Pusat Riset Perikanan Budidaya. IV(3): 50- 59.

Uchida, K. \& Fujimoto, M. 1933. Life History and M ethod of the Corean Snake-Head Fish, Ophiocephalus argus. Bulletin of the fishery Experiment Station of the Government-General of Chosen No. 3 (Series C. No. 1). p. 89-91.

Weber, M. \& Beaufort, L.F.D. 1922. The Fishes of the IndoAustralian Archipelago. Vol IV. p 312-330.

www.practicalfishkeeping.co.uk. Serial online 19 Februari 2008.

www.snakeheads.org. Serial online2001-2006. 